\title{
Site-Floristic Variability of Foxteil Meadows in Poland
}

\author{
Anna Kryszak, Jan Kryszak, Agnieszka Klarzyńska and Agnieszka Strychalska \\ Department of Grassland and Natural Landscape Sciences, Poznań University of Life Sciences, Dojazd 11, Poznań 60632, Poland
}

Received: April 10, 2015 / Accepted: May 13, 2015 / Published: May 30, 2015.

\begin{abstract}
On the basis of multifaceted investigations of approximately 600 phytosociological surveys of foxtail meadows taken in years 2002-2012 in river valleys with the assistance of the Braun-Blanquet method, the authors carried out evaluation of the floristic composition with respect to phytosociological structure, floristic variability, degree of synanthropisation and life form structures. In addition, they ascertained the dependence of floristic variability of Alopecuretum pratensis phytocenoses on site conditions determined using: the phytoindication method and the laboratory analyses assessed the soil content of available forms of $\mathrm{P}$ and $\mathrm{K}$ and of Mg. The greatest areas among the recognised syntaxons are taken up by patches of a typical sub-association developed in fresh sites on soils of lightly acid reaction and moderate nitrogen availability. Floristic variability of Alopecuretum pratensis is characterised by: presence in the phytosociological structure of species characteristic for other syntaxons, floristic abundance and botanical structure, domination of species of the $1^{\text {st }}$ and $2^{\text {nd }}$ degree of stability, high proportion of synanthropic species, values of the floristic diversity index (H'), natural and fodder score values. Geobotanical variability of foxtail meadows confirms difficulties with unequivocal determination of the systematic position of the Alopecuretum pratensis association.
\end{abstract}

Key words: Foxtail meadows, floristic variability, habitat conditions.

\section{Introduction}

Changes in site conditions and utilisation affect the development and diversification of anthropogenic plant communities, among others, meadow communities [1-3].

Meadow foxtail meadows (Alopecuretum pratensis) in river valleys undergo continuous transformations which are the outcome of changes in site and human activities. They occupy sites characterised by varying moisture conditions between communities of the Molinietalia order and communities of fresh sites from the Arrhenatheretalia order and are known for their complex floristic structure. The above presented site scale of occurrence of Alopecuretum pratensis meadows makes their systematic position debatable [4].

Kucharski and Michalska-Hejduk [5] reported that the following three sub-associations were distinguished in the Alopecuretum pratensis

Corresponding author: Anna Kryszak, Ph.D., research field: phytosociology.E-mail: agaklar@up.poznan.pl. association: Alopecuretum pratensis typicum, Alopecuretum pratensis deschampsietosum caespitosae, Alopecuretum pratensis phalaridetosum arundinaceae, while Trąba et al. [6]. Additionally, mention Alopecuretum pratensis typicum var. with Holcus lanatus.

Many researchers report appearing changes in the species composition of foxtail meadows [7-10]. They emphasise species impoverishment as well as a declining frequency of occurrence of species characteristic for this association.

The objective of this research project was to determine the impact of ecological conditions and utilisation on the variability of foxtail meadows developed in the river valleys.

\section{Materials and Methods}

The performed multifaceted analysis of approximately 600 phytosociological surveys taken with the assistance of the Braun-Blanquet method [11] in years 2002-2012 in valleys rivers of Polen. Phytosociological relevés were performed during the 
period from the middle of May to the middle of July from the area of $75-100 \mathrm{~m}^{2}$. After assigning relevés to the phytosociological system, the species were assessed in accordance with the Braun-Blanquet method with regard to:

- the number of occurrences in relation to the total number of phytosociological relevés of a given association, i.e. the constancy degree was determined,

- mean area cover by the species in the community, i.e. the covering coefficient was calculated according to the following formula:

Species covering coefficient $=\left(\sum\right.$ of mean percentage cover of the species in all relevés of the association in which it occurs/total number of relevés of the association) $\times 100$.

The floristic composition of meadows comprised with regard to their phytosociological structure floristic diversity, degree of synanthropisation, and structure of life forms. Phytosociological relevés were performed during the period from the middle of May to the middle of July from the area of $75-100 \mathrm{~m}^{2}$. After assigning relevés to the phytosociological system, the species were assessed in accordance with the Braun-Blanquet method with regard to:

Plant communities were analysed and identified by the communities code [12].

Floristic diversity was evaluated using the Shannon-Wiener index $H^{\prime}$ :

$$
H=-\sum\left(p_{\mathrm{i}} \cdot \ln p_{\mathrm{i}}\right)
$$

where $p_{i}$ is the cover proportion of the i-species [13].

The geographical-historic spectrum was described as the proportion (\%) of synanthropic and alien species in the community floristic composition [14]. Research results were obtained as an arithmetic mean from the calculated indices for the phytosociological relevés of a given community.

Site conditions carried out with the assistance of the phyto-indication method, i.e. with the help of indicator numbers developed by Ellenberg et al. [15]: moisture content $(\mathrm{F})$, soil reaction $(\mathrm{R})$ and nitrogen content in soil $(\mathrm{N})$. For all phytosociological surveys the authors calculated weighted averages of index values in relation to the quantity and next arithmetic averages of indices for the entire communities. In addition, for 10 representative phytosocilogical relevés of each syntax of the Alopecuretum pratensis, laboratory analyses were performed to assess the soil content of available forms of $\mathrm{P}$ and $\mathrm{K}$ (by Egner-Rhiem method) and of $\mathrm{Mg}$ (method of Schachtschabel).

\section{Results and Discussion}

\subsection{Floristic Variability of Alopecuretum Pratensis}

Until recently, communities of Molinio-Arrhenatheretea class had the character of spontaneous, semi-natural communities and the anthropogenic factor was restricted to periodical cutting or grazing, less frequently fertilisation or possibly regulation of water relations. In the present time, following utilisation intensification, the floristic composition of the majority of communities of this class undergoes transformations developing new phytocenotic systems. In this respect, foxtail meadows provide an example as they underwent considerable diversification as a result of changing site conditions combined with alterations in utilisation. Apart from most frequent participation of high proportions of Alopecurus pratensis, the authors can also find in the floristic composition of these meadows: Rumex acetosa, Taraxacum officinale, Ranunculus repens, Rumex crispus, Poa pratensis, Potentilla anserina, P. reptans, Deschampsia caespitosa, Achillea millefolium, and Phalaris arundinacea (Table 1).

Taking into consideration floristic composition similarities of the phytosociological surveys, the following 5 syntaxons were distinguished: Alopecuretum pratensis typicum, Alopecuretum pratensis phalaridetosum arundinaceae, Alopecuretum pratensis deschampsietosum caespitosae as well as variants of a typical sub-association, namely: periodically drying with Rumex acetosa and periodically marshy with Potentilla anserina-Potentilla reptans 
Table 1 Occurrence of species in Alopecurus pratensis phytocenoses.

\begin{tabular}{ll}
\hline Species & Cover degree \\
\hline Alopecurus pratensis & V \\
Rumex acetosa, Taraxacum officinale & IV \\
Achillea millefolium, Phalaris arundinacea, Poa pratensis, Potentilla anserina,, Ranunculus repens, & III \\
Deschampsia caespitosa, Potentilla reptans, Rumex crispus & \\
\hline
\end{tabular}

and occasionally grazed with Poa pratensis. The sub-association Alopecuretum pratensis is by far the most dominant element of the association.

The recognised syntaxons differ from one another with regard to their phytosociological structure. It is true that in all of them, species of the Molinio-Arrhenatheretea class constitute the highest proportion, nevertheless groups of distinctive species are clearly noticeable (Table 2).

The Alopecuretum pratensis phalaridetosum arundinaceae was recognised on the basis of a considerable proportion of characteristic species from the Phragmitetea class $(12 \%)$, i.e. presence of: Phalaris arundinaceae (V 2321) as well as Carex gracilis (I 25), Iris pseudoacorus (I 2). The floristic composition of Alopecuretum pratensis deschampsietosum caespitosae distinguishes itself by $20 \%$ proportion of species from the Molinietalia order, including the presence of: Deschampsia caespitosa (V 2312), Ranunculus repens (IV 737), Holcus lanatus (IV 956) as well as Rumex acetosa ((IV 145), Phalaris arundinacea (IV568). On the other hand, variants of Alopecuretum pratensis typicum with Rumex acetosa, with Potentilla anserina-Potentilla reptans and with Poa pratensis were recognised on the basis of distinct domination of diagnostic species. In the variant with Rumex acetosa, considerable stability and cover index were observed for: Poa trivialis (III 667), P. pratensis (III 458), whereas in the Potentilla anserina-Potentilla reptans variant-Rumex crispus (III 195), Plantago lanceolata (III 13) and in the variant with Poa pratensis-Achillea millefolium (IV 106), Taraxacum officinale (III 57) (Table 3).

However, it should be emphasised that some of the recognised communities are characterised by poor stability as evidenced by considerable proportions of species reaching the 1 st or 2 nd degree of stability. The proportion of such species was particularly high-approximately $80 \%$ of the floristic composition-in Alopecuretum pratensis typicum and in the variant with Rumex acetosa. Such distribution of stability can be associated with frequently changing

Table 2 Variability of the phytosociological structure of the recognised syntaxons (\%).

\begin{tabular}{lllllll}
\hline \multirow{2}{*}{ Plant species characteristic for: } & \multicolumn{7}{c}{ Syntaxon Alopecuretum pratensis* } \\
\cline { 2 - 7 } & typicum & ph.a. & d.c. & var. with R.a. & var. with P.a-P.r. & var. with P.p \\
\hline Molinio-Arrhenatheretea & 49.3 & 59.1 & 59.1 & 75.0 & 54.0 & 52.7 \\
Molinietalia & 17.1 & 16.7 & 16.7 & 21.4 & 21.0 & 16.5 \\
Arrhenatheretalia & 8.8 & 10.2 & 15.2 & 14.3 & 12.0 & 14.3 \\
Trifolio fragifetrae & 4.9 & 15.6 & 10.6 & 14.3 & 7.0 & 8.8 \\
Agrostietalia stoloniferae & 9.3 & 12.0 & 120 & 4.3 & 5.0 & 4.4 \\
Phragmitetea & 11.0 & 6.0 & 6.0 & 2.5 & 6.0 & 10.0 \\
Stellarietea mediae & 13.0 & 9.0 & 9.0 & 15.1 & 9.0 & 14.0 \\
Artemisietea vulgaris & 17.4 & 13.9 & 13.9 & 3.1 & 26.0 & 18.9 \\
Other species & &
\end{tabular}

* ph.a.-Alopecuretum pratensis phalaridetosum arundinaceae.

d.c.-Alopecuretum pratensis deschampsietosum caespitosae.

var. with R.a.-Alopecuretum pratensis typicum var. with Rumex acetosa.

var. with P.a-P.r.-Alopecuretum pratensis var. z Potentilla anserine-Potentilla reptans.

var. with P.p-Alopecuretum pratensis typicum var. with Poa pratensis. 
Table 3 Comparison of the degree of stability and cover index of selected plant species.

\begin{tabular}{|c|c|c|c|c|c|c|}
\hline \multirow{2}{*}{ Species } & \multicolumn{6}{|c|}{ Syntaxon Alopecuretum pratensis* } \\
\hline & typicum & ph.a. & d.c. & var. with R.a. & var. with P.a-P.r. & var. with P.p. \\
\hline Number of relevés & 287 & 102 & 75 & 33 & 45 & 81 \\
\hline \multicolumn{7}{|l|}{ Ch. I D. All Alopecurion } \\
\hline Alopecurus pratensis & V 4031 & V 2893 & V 2436 & V 3792 & V 2467 & V 2364 \\
\hline Glechoma hederacea & II 15 & - & - & I 83 & I 3 & II 15 \\
\hline Stellaria palustris & I 1 & II 103 & I 0.5 & I 92 & I 10 & I 5 \\
\hline Symphytum officinale & I 15 & $\mathrm{I} 2$ & - & - & I 7 & I 5 \\
\hline \multicolumn{7}{|l|}{ Ch.O. Molinietalia } \\
\hline Achillea ptarmica & I 12 & I 7 & - & - & - & I 46 \\
\hline Angelica sylvestris & I 1 & - & - & - & - & - \\
\hline Cirsium palustre & - & I 2 & I 1 & - & I 1 & - \\
\hline Deschampsia caespitosa & III 106 & III 86 & V 2312 & I 83 & I 4 & III 56 \\
\hline Eguisetum palustre & I 0.5 & - & I 219 & - & I 4 & I 5 \\
\hline Galium uliginosum & I 1 & I 7 & - & I 308 & I 4 & - \\
\hline Lotus uliginosus & I 1 & - & - & - & I 1 & - \\
\hline Lychnis flos cuculi & II 6 & I 2 & II 8 & - & I 4 & II 10 \\
\hline Sanguisorba officinalis & I 0.5 & - & - & - & - & - \\
\hline Taraxacum palustre & - & I 1 & - & - & - & - \\
\hline \multicolumn{7}{|l|}{ Ch.O. Arrhenatheretalia } \\
\hline Achillea millefolium & IV 151 & III 107 & III 81 & I 108 & II 47 & IV 106 \\
\hline Arrhenatherum elatius & I 7 & - & - & I 83 & I 3 & II 51 \\
\hline Bromus hordeaceus & II 90 & II 14 & - & - & I 1 & - \\
\hline Dactylis glomerata & II 110 & II 9 & I 7 & I 83 & - & II 207 \\
\hline Daucus carota & & - & & & & \\
\hline Heracleum sphondylium & II 32 & - & II 9 & - & I 7 & III 16 \\
\hline Leucanthemum vulgare & I 4 & - & - & - & & I 2 \\
\hline Lotus corniculatus & I 0.5 & I 90 & - & - & - & - \\
\hline Taraxacum officinale & IV 114 & - & II 19 & 108 & II 17,3 & III 57 \\
\hline \multicolumn{7}{|c|}{ Ch.O. Trifolio fragiferae-Agrostietalia stoloniferae } \\
\hline Agropyron repens & II 179 & III 87 & I 63 & I 92 & II 373 & I 50 \\
\hline Agrostis stolonifera & I 4 & II 43 & - & - & - & - \\
\hline Alopecurus geniculatus & I 4 & - & - & - & I 3 & I 5 \\
\hline Carex hirta & II 29 & I 1 & I 6 & - & II 9 & II 52 \\
\hline Festuca arundinbacaea & I 49 & III 81 & - & - & - & I 46 \\
\hline Lysimachia nummmularia & I 5 & - & I 6 & - & I 10 & I 5 \\
\hline Potentilla anserine & III 114 & III 86 & II 70 & - & IV 1460 & III 68 \\
\hline Potentilla reptans & III 74 & II9 & II 69 & I 308 & V 2053 & I 5 \\
\hline Ranunculus repens & III 113 & III 621 & IV 737 & I 300 & III 113 & III 106 \\
\hline Rumex crispus & III39 & III 80 & II 8 & I 108 & III 195 & II 7 \\
\hline \multicolumn{7}{|c|}{ Ch.Cl. Molinio-Arrhenatheretea } \\
\hline Agrostis gigantea & II 103 & III 80 & - & - & I 33 & I 50 \\
\hline Avenula pubescens & I 15 & - & - & - & - & - \\
\hline Cardamine pratensis & I 1 & - & - & I 92 & I 5 & I 1 \\
\hline Centarea jacea & I 1 & I 7 & - & - & - & - \\
\hline Cerastium holosteoides & I 9 & III 21 & IV 31 & II 167 & I 37 & I 2 \\
\hline Festuca pratensis & I 16 & - & I 6 & - & - & I 3 \\
\hline Festuca rubra & II 172 & - & II 456 & I 83 & I 287 & III 300 \\
\hline Holcus lanatus & II 146 & III 58 & IV 956 & - & II 77 & III 105 \\
\hline
\end{tabular}


Table 3 continued

\begin{tabular}{|c|c|c|c|c|c|c|}
\hline \multirow{2}{*}{ Species } & \multicolumn{6}{|c|}{ Syntaxon Alopecuretum pratensis* } \\
\hline & typicum & ph.a. & d.c. & var. with R.a. & var. with P.a-P.r. & var. with P.p. \\
\hline Number of relevés & 287 & 102 & 75 & 33 & 45 & 81 \\
\hline \multicolumn{7}{|c|}{ Ch.Cl. Molinio-Arrhenatheretea } \\
\hline Lathyrus pratensis & I 6 & - & I 1 & - & I 1 & - \\
\hline Leontodon hispidus & - & - & - & - & I 4 & - \\
\hline Phleum pretense & II 64 & III 16 & - & - & I 33 & I 46 \\
\hline Plantago lanceolata & II 75 & II 14 & II 19 & - & III 13 & III 60 \\
\hline Poa pratensis & III 149 & III 86 & I 219 & III 458 & II 353 & V 2114 \\
\hline Poa trivialis & I 12 & - & - & III 667 & I 153 & - \\
\hline Ranunculus acris & II 57 & III 93 & III 76 & I 92 & I 37 & II 14 \\
\hline Rumex acetosa & IV 121 & III 23 & IV 145 & V 1750 & III 91 & III 146 \\
\hline Trifolium pratense & I 11 & I 1 & & - & I 10 & II 10 \\
\hline Vicia cracca & I 16 & I 16 & I 6 & $\mathrm{I} 2$ & II 5 & I 5 \\
\hline \multicolumn{7}{|l|}{ Ch.All. Magnocaricion } \\
\hline Phalaris arundinacea & III 166 & V 2321 & III 568 & - & III 94 & II 45 \\
\hline Carex gracilis & II72 & I 25 & III 20 & - & III 41 & - \\
\hline Galium palustre & I 1 & - & I 1 & I 83 & II 43 & - \\
\hline Irs pseudoacorus & I 21 & I 2 & - & - & I 7 & - \\
\hline Poa palustris & II 78 & II 76 & - & - & I 153 & I 5 \\
\hline \multicolumn{7}{|l|}{ Ch.Cl.Phragmitetea } \\
\hline Eleocharis palustris & I 4 & - & - & - & - & I 1 \\
\hline Equisetum fluviatile & I 0.5 & - & - & - & - & - \\
\hline Glyceria maxima & I 4 & - & - & - & - & - \\
\hline Phragmites australis & I 1 & - & - & - & - & I 1 \\
\hline Sium latifolia & I 0.5 & - & - & - & - & - \\
\hline
\end{tabular}

* ph.a.-Alopecuretum pratensis phalaridetosum arundinaceae.

d.c.-Alopecuretum pratensis deschampsietosum caespitosae.

var. with R.a-Alopecuretum pratensis typicum var. with Rumex acetosa.

var. with P.a-P.r.-Alopecuretum pratensis var. z Potentilla anserine-Potentilla reptans.

var. with P.p.-Alopecuretum pratensis typicum var. with Poa pratensis.

site conditions, primarily, moisture content and the applied utilisation, i.e. frequency of cutting or occasional grazing.

The total of 222 plant species was inventoried in the meadow sward of the Alopecuretum pratensis association, although the identified syntaxons vary among themselves with regard to species abundance. The greatest number of species was recorded in Alopecuretum pratensis typicum, Alopecuretum pratensis phalaridetosum arundinaceae and Alopecuretum pratensis typicum var. with Poa pratensis phytocenoses and their numbers were very small in patches with Rumex acetosa (Table 4).

Floristic composition of foxtail meadows is dominated by synanthropic native species - apophytes (Table 5). They constitute a particularly high percentage in phytocenoses with Rumex acetosa. Non-synanthropic species-spontaneophytes-occur most numerously in the site syntaxons characterised by the highest moisture content. Their utilisation depends on the length of the flooding period. The stagnating water affects the fertilization and utilisation intensity favouring maintenance of greater natural character of meadow communities [16]. On the other hand, foreign species were recorded primarily in the sward utilised intensively either in the form of cutting or occasional grazing.

Life forms are, first and foremost, a reflection of 
climatic conditions affecting plants. According to Chmiel [17], the growing anthropo-pressure can change proportions between individual groups. Hemicryptophytes dominate in the floristic composition of all the examined syntaxons of foxtail meadows. Their share ranges from $51 \%$ in Alopecuretum pratensis typicum and Alopecuretum pratensis phalaridetosum arundinaceae to over $80 \%$ in Alopecuretum pratensis typicum var. with Rumex acetosa. Hydrophytes and helophytes were found absent in phytocenoses with Rumex acetosa developed in the least moist or even drying sites. At the same time, in the wettest conditions of Alopecuretum pratensis phalaridetosum arundinaceae nearly $7 \%$ proportion of hydrophytes and helophytes was recorded (Table 5).

Table 4 Floristic diversity of recognised communities.

\begin{tabular}{llll}
\hline \multirow{2}{*}{ Plant communities } & \multicolumn{2}{c}{$\begin{array}{c}\text { Number of species } \\
\text { Shannon-Wiener floristic }\end{array}$} \\
\cline { 2 - 3 } Alopecuretum pratensis typicum & total & mean/relevé & diversity index-H' \\
\hline Alopecuretum pratensis phalaridetosum arundinaceae & 66 & 25.2 & 2.65 \\
Alopecuretum pratensis deschampsietosum caespitosae & 56 & 20.7 & 1.72 \\
Alopecuretum pratensis var. with Potentilla anserine-Potentilla reptans & 100 & 16.7 & 1.62 \\
Alopecuretum pratensis typicum var. with Rumex acetosa & 28 & 18.9 & 1.84 \\
Alopecuretum pratensis typicum var. with Poa pratensis & 70 & 21.9 & 1.35 \\
\hline
\end{tabular}

Table 5 Characterisation of species composition of Alopecuretum pratensis.

\begin{tabular}{|c|c|c|c|c|c|c|}
\hline \multirow{3}{*}{ Utilisation } & \multicolumn{6}{|c|}{ Syntakson Alopecuretum pratensis* } \\
\hline & typicum & ph.a. & d.c. & var. with R.a & var. with P.a-P.r. & var. with $P . p$ \\
\hline & $2-3 \times$ cut & $2 \times$ cut & $1-2 \times$ cut & $1 \times$ cut & $\begin{array}{l}1 \times \text { cut } \\
\text { and grazing }\end{array}$ & $\begin{array}{l}2 \times \text { cut } \\
\text { and grazing }\end{array}$ \\
\hline \multicolumn{7}{|c|}{ Structure of plant fodder value score groups (\%) } \\
\hline Grasses & 36.1 & 26.7 & 21.4 & 20.3 & 18.0 & 22.0 \\
\hline Legume & 9.9 & 0.6 & 3.1 & 5.4 & 7.0 & 13.5 \\
\hline Other species & 54.0 & 72.7 & 75.5 & 74.3 & 75.0 & 64.5 \\
\hline \multicolumn{7}{|c|}{ Geographic-historic structure (\%) } \\
\hline Apophytes & 77.8 & 64.1 & 75.6 & 84.6 & 72.0 & 76.9 \\
\hline Archeophytes & 4.8 & 7.1 & 2.8 & - & 3.0 & 5.5 \\
\hline Kenophytes & 3.2 & - & 3.0 & - & 1.0 & 2.2 \\
\hline \multicolumn{7}{|c|}{ Structure of life groups according to Raunkiaer (\%) } \\
\hline Hemicryptophytes & 51.2 & 51.5 & 60.7 & 80.1 & 63.0 & 62.6 \\
\hline Geophytes & 12.7 & 16.7 & 13.1 & 10.7 & 14.0 & 12.1 \\
\hline Terophytes & 13.7 & 15.2 & 8.2 & 5.6 & 9.0 & 12.1 \\
\hline Hydrophyte and helophytes & 3.0 & 6.8 & 3.3 & - & 3.0 & 2.2 \\
\hline Other species & 19.4 & 9.8 & 14.7 & 3.6 & 11.0 & 11.0 \\
\hline \multicolumn{7}{|c|}{ Species structure according to persistence (\%) } \\
\hline Perennial plant & 71.2 & 74.2 & 82.1 & 76.7 & 80.0 & 76.9 \\
\hline Annual plant & 13.2 & 10.6 & 7.1 & 5.6 & 8.0 & 7.7 \\
\hline Annual or biennial plant & 8.6 & 10.6 & 5.4 & 10.6 & 8.0 & 11.0 \\
\hline Biennial plant & 7.0 & 4.6 & 5.4 & 7.1 & 4.0 & 4.4 \\
\hline \multicolumn{7}{|c|}{ * ph.a.-Alopecuretum pratensis phalaridetosum arundinaceae. } \\
\hline \multicolumn{7}{|c|}{ d.c.-Alopecuretum pratensis deschampsietosum caespitosae. } \\
\hline \multicolumn{7}{|c|}{ var. with R.a.-Alopecuretum pratensis typicum var. with Rumex acetosa. } \\
\hline \multicolumn{7}{|c|}{ var. with P.a-P.r.-Alopecuretum pratensis var. z Potentilla anserine-Potentilla reptans. } \\
\hline
\end{tabular}


Perennials, i.e. species deciding about the stability of communities were distinctly dominant in patches of recognised syntaxons. Majority of them were dicotyledonous species which, together with grasses, guarantee the development of persistent and valuable sward. The observed annuals and biennials were recorded mostly with the 1 st or 2 nd degree of stability reducing the persistence of these phytocenoses (Table 6).

\subsection{Site Variability of Alopecuretum pratensis}

The recognised syntaxons show variability of site conditions associated, primarily, with their distribution in river valleys. In areas characterised by the longest flooding periods, patches of Alopecuretum pratensis phalaridetosum arundinaceae sub-association develop. Its patches border with phytocenoses from the Magnocaricion alliance and Alopecuretum pratensis deschampsietosum caespitosae or Alopecuretum pratensis typicum and Alopecuretum pratensis typicum var. with Potentilla anserina-Potentilla reptans associations. However, further away from riverbeds, sometimes on small elevations, foxtail meadows with Rumex acetosa developed whose sites exhibit the lowest moisture content. They neighbour, as confirmed by the phytosociological structure of communities, with Alopecuretum pratensis typicum var. with Poa pratensis phytocenoses as well as with patches of associations of the Arrhenatheretalia order.

Many researchers emphasise the important role of site conditions in developing plant communities [18-20]. This opinion is also corroborated by the site conditions of foxtail meadow communities. Moisture conditions exert a decisive impact on the occurrence and floristic diversity of Alopecuretum pratensis patches (Table 7).

Phytocenoses developed in sites with higher moisture content and high soil nitrogen concentrations as well as low phosphorus, potassium and magnesium contents are characterised by small participation of species from the Fabaceae family. At the same time, the highest numbers of these plants as well as grass species were recorded in Alopecuretum pratensis typicum and Al.p. poetosum pratensis which occurred

Table 6 Comparison of the distribution of stability degrees of species in the recognised Alopecuretum pratensis syntaxons.

\begin{tabular}{lllllll}
\hline \multirow{2}{*}{ Syntaxon Alopecuretum pratensis } & \multicolumn{4}{c}{ Classes of presences (constancy) } & \multicolumn{1}{c}{ Total plant species } \\
\cline { 2 - 7 } number
\end{tabular}

Table 7 Variability of site conditions of Alopecuretum pratensis.

\begin{tabular}{|c|c|c|c|c|c|c|}
\hline \multirow[t]{2}{*}{ Syntakson } & \multicolumn{3}{|c|}{ Ellenberg's index* } & \multicolumn{3}{|c|}{$\begin{array}{l}\text { Concentrations } \\
\left(\mathrm{mg} \cdot \mathrm{kg}^{-1} \text { of soil }\right)\end{array}$} \\
\hline & $\mathrm{F}$ & $\mathrm{R}$ & $\mathrm{N}$ & $\mathrm{P}$ & $\mathrm{K}$ & $\mathrm{Mg}$ \\
\hline Alopecuretum pratensis typicum & 5.4 & 3.1 & 5.7 & 126.3 & 108.7 & 128.2 \\
\hline Alopecuretum pratensis phalaridetosum arundinaceae & 6.6 & 5.0 & 6.0 & 98.0 & 70.7 & 71.7 \\
\hline Alopecuretum pratensis deschampsietosum caespitosae & 6.4 & 3.3 & 4.5 & 105.3 & 60.2 & 116.6 \\
\hline $\begin{array}{l}\text { Alopecuretum pratensis typicum var. with Potentilla } \\
\text { anserine-Potentilla reptans }\end{array}$ & 5.8 & 3.2 & 5.5 & 190.5 & 75.6 & 145.1 \\
\hline Alopecuretum pratensis typicum var. with Poa pratensis & 5.2 & 3.1 & 5.7 & 140.7 & 120.5 & 90.1 \\
\hline Alopecuretum pratensis typicum var. with Rumex acetosa & 4.7 & 3.0 & 5.5 & 80.4 & 127.2 & 47.5 \\
\hline
\end{tabular}

*Ellenberg's index: F-soil moisture; $\mathrm{R}$-soil reaction; $\mathrm{N}$-nitrogen content in soil. 
in sites with moderate moisture content, soil reaction from lightly acid to neutral and moderate soil nitrogen and high potassium concentration. Simultaneously, in sites with moderate moisture content and higher soil nitrogen concentrations, more hemicryptophytes and synanthropic species were recorded.

Many researchers emphasise floristic variability of foxtail meadows resulting from both dynamic interrelations of plant communities and occurrence of floodings [7, 8, 21-23]. It constitutes the basis for the recognition of lower phytosociological entities: Alopecuretum pratensis var. z Lotus uliginosus [10], A.p. poetosum angustifoliae [7] and A.p. phalaridetosum arundinaceae [24] and included it in the Arrhenatherion alliance. Considerable variability of foxtail meadows contributed to the discussion about their place in the phytosociological system. Earlier, there was for near 2000 year the foxtail meadows were classified in the Arrhenatheretalia order of the Arrhenatherion alliance. Later, their systematic position was verified and included in the Alopecurion alliance of the Molinietalia order [2, 4, 12, 25, 26]. Floristic composition of the recognised Alopecuretum pratensis syntaxons indicates domination of meadow plant species of areas flooded with flowing waters, i.e. periodically excessively moist, which justifies its inclusion in the Molinietalia order. At the same time, the recorded considerable share in phytocenoses of Arrhenatheretalia order species confirms its significant floristic variability and explains earlier difficulties with an unequivocal allocation in the system.

It is worth emphasising that the recognised syntaxons differ among themselves regarding floristic wealth as well as botanical, life form and species persistence structure. This considerable floristic variability of the Alopecuretum pratensis association phytocenoses is associated with site conditions as well as meadow utilisation as confirmed by Kryszak and Grynia [8, 27-30]. They stress that syntaxons developed in dry sites as well as in intensively utilised areas are characterised by poor floristic composition. The highest numbers of species among the analysed Alopecuretum pratensis units were recorded in the Alopecuretum pratensis typicum phytocenoses developed in shortly flooded phytocenoses, while the smallest numbers - in Al.p. typicum var. with Rumex acetosa developed in dry sites as evidenced by values of the diversity coefficient ranging from $\mathrm{H}^{\prime}=1.35$ for Alopecuretum pratensis typicum var. with Rumex acetosa to $\mathrm{H}^{\prime}=2.45$ for Al. p. typicum. The number of plant species recorded in the sward of Alopecuretum pratensis syntaxons depended on the content of phosphorus in the soil; their higher numbers were observed when the content of this element in the soil was higher. Also Janssens et al. [31, 32] as well as Tracy, Sanderson [33] reported a similar correlation.

Alopecuretum pratensis syntaxons also differ with regard to the proportions of synanthropic species, often expansionary [34]. They are more numerous in moderately moist and drying sites where sward can be utilised systematically. Kryszak et al. [23] stress that two cuts and occasional grazing support the occurrence of greater numbers of synanthropic species, including foreign species. Communities situated along rivers, in particular, acting as bridgeheads are sensitive to the encroachment of alien species [25].

Recapitulating, the results of the authors' investigations indicate that such considerable site-floristic variability of foxtail meadows contributes to the diversity of their natural value and fodder score.

\section{Conclusions}

Phytosociological structure of Alopecuretum pratensis in which species of the Molinietalia order dominate justifies its current position in the phytosociological system and its floristic variability provides a sound basis for the recognition of lower phytosociological entities.

The identified lower units of Alopecuretum pratensis are most frequently characterised by poor stability as confirmed by the domination of species 
reaching the 1 st and 2 nd degree of stability.

Floristic variability of Alopecuretum pratensis phytocenoses finds its expression in the total number of species from 205 to 28 and mean number in a phytosociological survey from 23.8 to 15.8 , proportion of synanthropic species from $71.2 \%$ to $85.6 \%$, botanical structure and species stability.

Site conditions, primarily moisture and phosphorus content and utilisation, exert the strongest impact on the development of Alopecuretum pratensis and its floristic variability.

\section{References}

[1] Joyce, C. B., and Wade, P. M. 1999. European Wet Grasslands: Biodiversity, Management and Restoration. Chichester: J. Wiley \& Sons.

[2] Botta-Dukat, Z., Chytry, M., Hajkova, P., and Havlova, M. 2005. "Vegetation of Lowland Wet Meadows along a Climatic Continentality Gradient in Central Europe." Preslia 77: 89-111.

[3] Pärtel, M., Bruun, H., and Sammul, M. 2005. "Biodiversity in Temperate European Grasslands: Origin and Conservation." Grassld. Sci. Eur. 10: 1-14.

[4] Sendžikaitè, J., Pakalnis, R., and Avižienè, D. 2008. "The Status of Lithuanian Natural and Seminatural Meadow Communities and Their Preservation Possibilities." Acta Biol. Univ. Daugavp 8 (1):145-51.

[5] Kucharski, L., and Michalska-Hejduk, D. 1994. "Review of Meadow Communities from Molinio-Arrhenatheretea Distinquished in Poland." Wiad. Bot. 38 (1/2): 95-9 (in Polish).

[6] Trąba, Cz., Wolański, P., and Oklejewicz, K. 2006. "Floristic Diversity of Selected Non-Forest Communities in the San valley." Annales UMCS 61: 267-75 (in Polish).

[7] Borysiak, J. 1994. "The Structure of the Alluvial Land Vegetation in the Middle and Lower Course of Warta River." Wyd. Naukowe UAM 254 (in Polish).

[8] Kryszak, A., and Grynia, M. 2001. "Floristic Diversity and Economic Value of the Alopecuretum Pratensis Association in Western Poland." Grassland Sciences in Europe 6: 164-6.

[9] Schalitz, G., and Behrend, A. 1997. "Vegetation and the Problems on Its Restoration in the Lower Oder Valley." Grassland Science in Europe 2: 243-8.

[10] Szoszkiewicz, J. 1968. Plant Communities of Alluvial Grassland in the Warta Valley, Molinio-Arrhenatheretea Class Communities. Vol. A. Prace Kom. Nauk Roln. i Kom. Nauk Leśn. PTPN 24: 283-325 (in Polish).
[11] Braun-Blanquet, J. 1964. Pflanzensoziologie. Vien: Springer Verlag.

[12] Matuszkiewicz, W. 2012. “A Quide to Identofication of Plant Communities in Poland. Vademecum Geobotanicum." Wyd. Nauk. PWN Warsaw 537 (in Polish).

[13] Magurran, A. E. 2004. Measuring Biological Diversity. Malden: Blackwell Publishing.

[14] Jackowiak, B. 1990. "Anthropogenic Changes of the Flora of Vascular Plants of Poznań.” Wyd. Nauk. UAM 42: 232 (in Polish).

[15] Ellenberg, H., Weber, H. E., Dull, R., Wirth, V., Werner, W., and Paulissen, D. 1992. Zeigerwerte von Pflanzen in Mitteleuropa. Göttingen: Erich Goltze KG.

[16] Joyce, C. 2001. "The Sensitivity of a Species-Rich Flood-Meadow Plant Community to Fertilizer Nitrogen: The Luznice River Floodplain Czech Republic.” Plant Ecol. 155: 47-60.

[17] Chmiel, J. 1993. "Flora Vascular Plants of the Eastern Part of the Gniezno Lake District and Its Transformation Under the Influence of Man in the $19^{\text {th }}$ and $20^{\text {th }}$ Centuries." Atlas of the distribution of plants. Pr. Zakł. Taks. Roślin UAM w Poznaniu, pp.112. (in Polish).

[18] Diekmann, M. 2003. "Species Indicator Values as an Important Tool in Applied Plant Ecology-a Review." Basic and Applied Ecology 4: 493-506.

[19] Havlova, M., Chytry, M., and Tichy, L. 2004. "Diversity of Hay Meadows in the Czech Republic: Major Types and Environmental Gradients." Phytocoenologia 34: 551-67.

[20] Wamelink, G. W. W., Goedhart, P. W., Malinowska, A. H., Frissel, J. Y., Wegman, R. J. M., Slim, P. A., and van Dobben, H. F. 2011. "Ecological Ranges for the $\mathrm{pH}$ and $\mathrm{NO}_{3}$ of Syntaxa: A New Basis for the Estimation of Critical Loads for Acid and Nitrogen Deposition." Journal of Vegetation Science 22: 741-9.

[21] Sauder, A. 2007. "Vegetation of Wet Meadows (Order Molinietalia Caeruleae W. Koch 1926) in the Eastern Part of Silesia Upland." Grassland Science in Poland 10: 159-72 (in Polish).

[22] Karagianni, P., Tiniakou, A., and Georgiadis, T. 2008. “A Distribution of Habitat Types along the Rivers of W. Greece: A Case Study." Fresenius Environmental Bulletin 17 (6): 713-21.

[23] Kryszak, A., Kryszak, J., and Grynia, M. 2005. "Floristic Diversity of Flooded Meadows." Grassland Sciences in Europe 10: 264-7.

[24] Grynia, M., Kroehnke, R., and Mikiciuk, J. 1967. "Major Meadow Vegetation Communities in the Mogielnica Valley." Prace Kom. Nauk Roln. i Kom. Nauk Leśn. PTPN 23 (1): 95-130 (in Polish).

[25] Balatova-Tulackova, E. 1981. "Beitrag zur Syntaxonomic 
der Wiesen-Hochstandengesellschaften.” In Proceedings of Internat. Symposien IV, Rinteln 1980, 375-84.

[26] Dierschke, H. 1994. "Syntaxonomical Survey of Molinio-Arrhenatheretea in Central Europa." Colloques Phytosociologiques 23: 387-99.

[27] Mosek, B., and Miazga, S. 2006. "Phytosociological Differentiation of Plant Communities in Meliorated River Valleys of the Lublin Region." Annales Universitatis Mariae Curie-Skłodowska 61: 377-87 (in Polish).

[28] Kryszak, A., Kryszak, J., Strychalska, A., and Klarzyńska, A. 2012. "The Effect of Utilisation on the Floristic Composition of Meadow Communities." J. of Life Sci. 6: 1061-7.

[29] Myklestad, Å., and Sætersdal, M. 2004. "The Importance of Traditional Meadow Management Techniques for Conservation of Vascular Plant Species Richness in Norway." Biol. Conserv. 118: 133-9.

[30] Schellberg, J., Möseler, B. M., Kühbauch, W., and Rademacher, I. F. 1999. "Long-Term Effect of Fertiliser on Soil Nutrient Concentration, Yield, Forage Quality and Floristic Composition of a Hay Meadow in the Eifel Mountains." Germany. Grass Forage Sci. 54:
195-207.

[31] Janssens, F., Peeters, A., Tallowin, J. R. B., Bakker, R. M., Fillat, F., and Oomes, M. J. M. 1998. "Relation between Soil Chemical Factors and Grasslands Diversity." Plant Soil 202: 69-78.

[32] Marini, L., Scotton, M., Klimek, S., Isselstein, J., and Pecile, A. 2007. "Effects of Local Factors on Plant Species Richness and Composition of Alpine Meadows." Agriculture, Ecosystems and Environment 119: 281-8.

[33] Tracy, B., and Sanderson, M. A. 2000. "Patterns of Plant Species Richness in Pasture Lands of the Northeast United States." Plant Ecol. 149: 169-180.

[34] Kryszak, A., Kryszak, J, Klarzyńska, A., and Strychalska, A. 2009. "Influence of Expansivenes of Select Plant on Floristic Diversity of Meadow Communities." Polish J. Environ. Stud. 18 (6): 1203-10.

[35] Miller, N., and Okuda, S. 1998. "Invasion of Alien Plants in Flooplains - a Comparison of Europe and Japan." In Plant Invasions: Ecological Mechanisms and Human Responses, edited by Starfinger, U., Edwards, K., Kowarik, I., and Williamson, M. Leiden: Backhuys Publishers. 